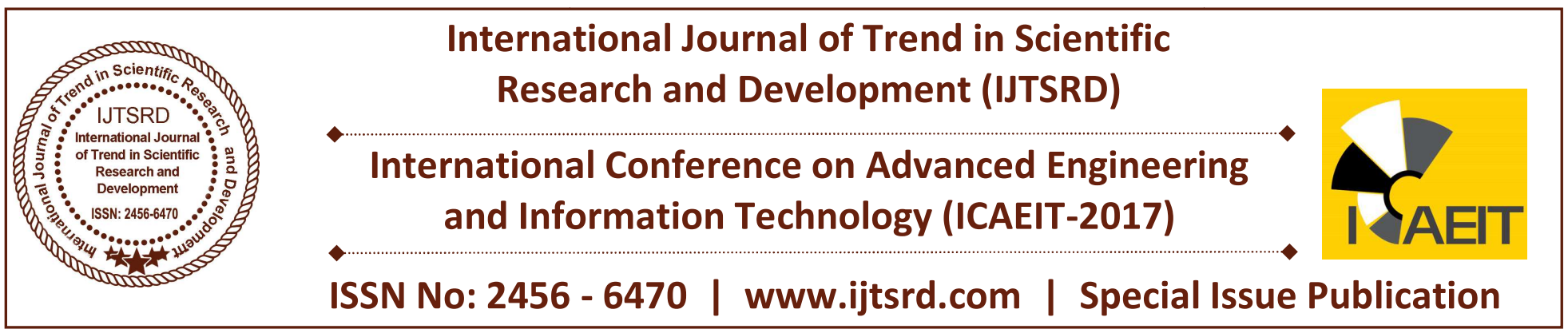

\title{
Development of Concrete Filled Steel Tube (CFST): A Review
}

\author{
Nazrul Azmi A. Z., Petrus C., Yazmin S. H. \\ Faculty of Built Envirenment, Kolej Universiti Linton, Mantin, Negeri Sembilan, Malaysia
}

\begin{abstract}
Concrete filled steel tube (CFST) structure offers numerous structural benefits, and has been widely used in civil engineering structures. This paper reviews the development of concrete-filled steel tubular structures members. The research development on CFST structural members in most recent years is summarized and discussed. Some construction projects utilizing CFST members are also introduced. Finally, some concluding remarks are made for CFST members.
\end{abstract}

Keywords: Concrete filled steel tube (CFST), members, design consideration, construction project.

\section{INTRODUCTION}

Concrete filled steel tube (CFST) is a composite structure where the steel hollow section is filled up with concrete. Steel hollow section is used as permanent formwork as well as reinforcement for the structure and the concrete will be poured inside the hollow section. CFST columns are a structural system with excellent characteristics structurally and economically as compared to other types of columns such as reinforced concrete columns and steel columns.

CFST offers many structural benefits such as high compressive strength and ductility, excellent earthquake resistance and able to reduce cost and duration of the constructions. These advantages have been widely exploited and have led to the extensive use of CFST in civil engineering structures. Many developed and earthquake countries such as United State, China and Australia have been done many researches and use the system in structural practices.

\section{CFST section and materials}

\subsection{Steel hollow section}

Normally there are three typical cross-section for CFST where the concrete were filled in square hollow section (SHS), rectangular hollow section (RHS) and circular hollow section (CHS). Figure 1 (a) shows the typical cross-section of CFST where the outer dimensions are noted as B and D, while the thickness is noted as $t$. In previous research, the CHS give a better performance in concrete confinement and higher load bearing capacity due to the load distributed uniformly though out the concrete core section compare to the CFST with SHS and RHS. The surface local buckling most likely occurs in flat surface of SHS and RHS thus reduce the confinement effect of the concrete core. However, the square and rectangular CFST are still increasingly used in constructions due to easier design in beam-column connection and easy to fabricate the sections. There are also other crosssection shape of the steel hollow section such as polygon, ellipse and round ended rectangular as shown in Figure 1 (b) for aesthetic appearance in the construction.

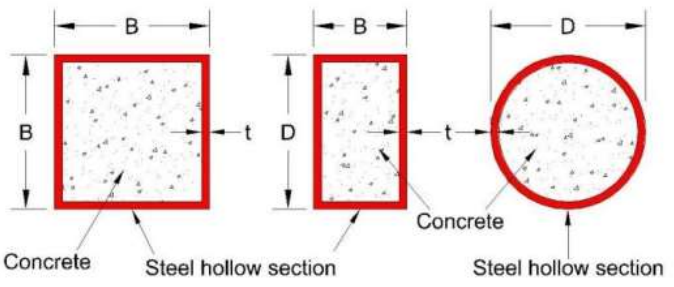

(a)
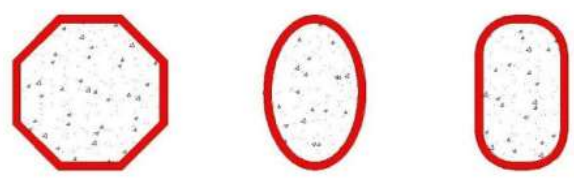

(b)

Figure1. Typical cross-section of CFST (Yang et al., 2012) 
Apart from the typical cross-section of CFST shown in Figure 1, there are also other types of CFST that has been studied throughout the years. Figure 2 shows the most common type of CFST used in the construction such as CFST with additional reinforce, concrete filled steel double-skin tubes and CFST with stiffeners. The additional reinforcement bar as shown in Figure 2 (a) usually for enhance load capacity with minimum size of column and did not change column profiles. The contribution of reinforcement bars to the column capacities can be considered as the combined capacities of the concrete-filled steel tubular parts and the structural steel bar. The reinforcement bars have to be taken into account for the resistance of the column since they are well anchored in the concrete.
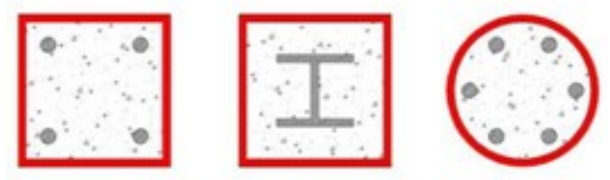

(a) CFST with additional reinforcentent
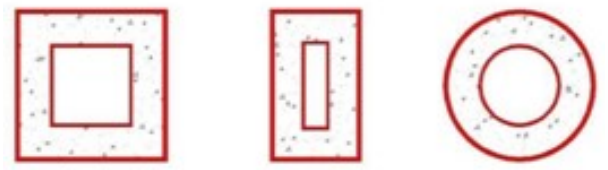

(b) Concrete filled steel double-akin tubes (CFSDT)

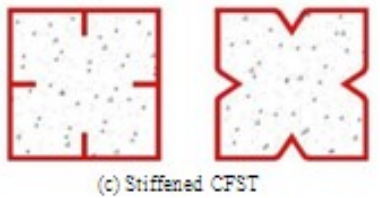

Figure2. Other types of CFST (Yang et al., 2012)

Concrete filled steel double-skin tubes (CFSDT) consist outer and inner hollow sections and filled the concrete in between the steel hollow sections as shown in Figure 2 (b). Yang et al. (2012), Hassanein et al. (2013) and Li et al. (2014) have done a number of studies of CFSDT and proved that CFSDT have better performances compare to typical CFST. CFSDT can be design for large cross-section member with smaller thickness of the steel hollow section and reduce the self- weight due to the less usage of concrete. CFSDT has high bending stiffness that avoids instability under external pressure and have higher fire resistance than the regular CFST columns, due to the inner hollow section being protected by the sandwiched concrete during fire. Furthermore, different materials can be utilized for the inner and outer hollow section such as corbon steel and stainless steel use for the inner and outer hollow section respectively in order to have the additional advantages of esthetics as well as corrosion resistance.

In normal CFST column, especially the square and rectangular section, after the composite member reach the ultimate strength, normally the local buckling will occur at the steel hollow section. This will be a major problem to apply the thin walled as the hollow section for the composite column. By adding transverse or longitudinal stiffeners into the steel hollow section, the strength and ductility of the composite column can be improved. The stiffeners can be welded to the inner face of the steel hollow section or fabricate using lip angle to form the hollow section with stiffeners. Studies done by Tao et al. (2005) and Clotilda et al. (2010, 2011) shows that the longitudinal improved the performance of concrete filled thin walled steel column and also delay the local buckling of the thin walled surface. Figure 2 (c) shows the CFST with stiffeners.

\subsection{Concrete infilled}

The normal weight concrete or high strength concrete can be used as the infilled for the concrete filled steel tubes. Typically, normal weight concrete is used for the mid-rise building construction and for the high-rise constructions usually the high strength concrete will be used. There are also other type of concrete been used to filled into the hollow section such as lightweight concrete, self-compacting concrete and concrete mixed with fly ash.

Most of the design code such as Eurocode 4 (EC4), American National Standard Institute (ANSI) and Australian Standard (AS4100) state that for the lightweight concrete, the characteristic strength of the concrete should not less than $20 \mathrm{MPa}$ to be used as infilled. The self-compacting concrete usually used to ensure the construction quality of the core concrete. Self-compacting concrete can be used in filling the hollow section without excessive vibration, which could be beneficial if some of the hollow sections are arranged with diaphragms near the connection zone. Han et al. (2005) showed that self-compacting concrete exhibited high levels of energy dissipation and ductility for the concrete filled steel tube columns and the load carrying capacities are similar with columns with normal concrete.

\section{Composite behavior}


As individual, concrete good for compressive strength, while steel good for tensile strength. Structurally, the existence of concrete delaying the local buckling of the steel tube thus stabilizes the column structure as a whole (Choi, 2004). The inward buckling that occurred in the hollow steel section is prevented due to existence of concrete, which causes the steel to deform outwardly at substantially larger strain than that of a hollow section. In contrast, the steel tube provides confinement effect to the concrete causing it to be under tri-axial stress state which in turn, results in an increased of the concrete compressive strength. It has also been shown that the steel tube provides well-distributed reinforcement located at the most efficient position (Fam, 2000 and Han et al., 2014). Figure 3 shows the failure mode of steel hollow section, concrete and CFST under compression load.
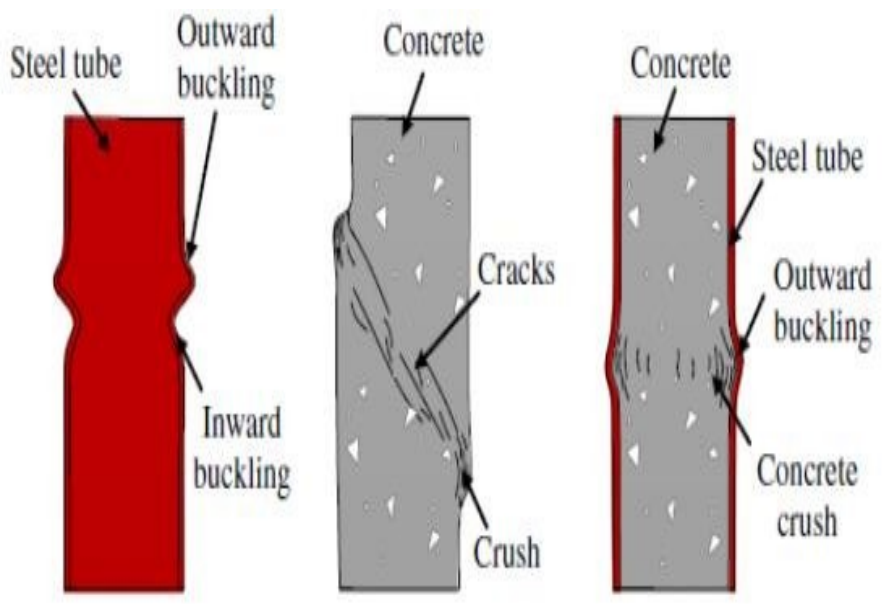

Figure3. Failure mode of Steel hollow section concrete and CFST (Han et al., 2014)

Figure 4 shows a comparison of the ultimate strength that has been conduct by Han et al. (2104) between a steel hollow section column, a reinforced concrete column and a concrete filled steel tube column without steel reinforcement and the loaddisplacement relationship of the columns. The geometric and material strength of these columns are all similar. It can be seen that the strength of concrete filled steel tube are even larger than reinforced concrete (RC) column and combine strength of RC and steel hollow column. The ductility of the concrete filled steel tube column are also significantly improve compare to the $\mathrm{RC}$ column.
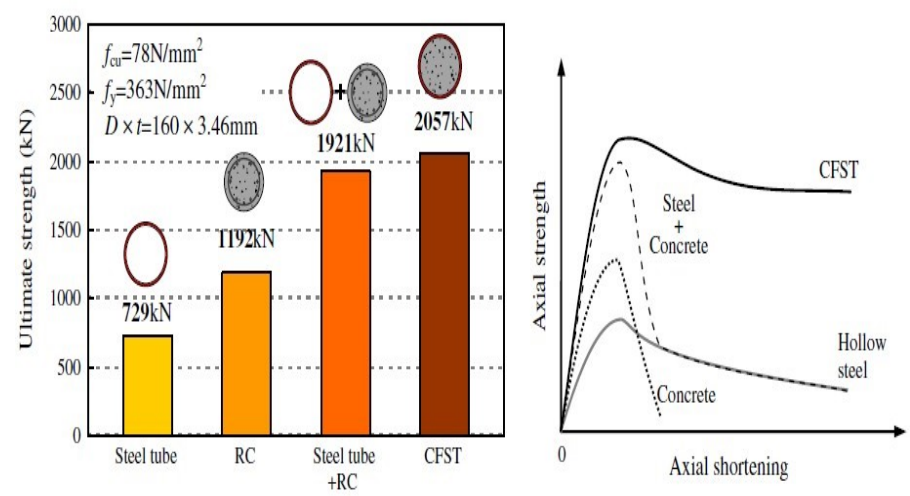

Figure4. Comparison of axial compressive behavior of CFST stub column. (Han et al., 2014)

\section{Connection}

Previously, the only method for the connection for the steel hollow section was using welding system due to the difficulty to access the interior of steel hollow section to fastened normal bolts and nuts to make the connections. By using welding, the connection of steel hollow section has high rigidity thus gives better performances in moment resistance connection. Alostaz and Schneider (1996) and Schneider and Alostaz (1998) conducted studies on different types of beam-column connections such as simple welded connection, diaphragm connection, extending the steel beam through the steel tube and added weldable bar on top and bottom of the simple welded connection. Some of the connections show very outstanding performances in the moment resisting and inelastic cyclic behaviour while the others are not. The most out standing is the steel beam extended through the steel tube. This connection exhibits stable strain- hardening behavior and developes a full plastic hinge in the beam-column connection and it can be used in regions of high seismic risk.

However, the use of these types of connections has not always been convenient in construction practice. Considerable work in erection is required, in addition to extensive welding and high tolerances required in detailing. This type of connection require professional man power to do the welding work and it is time consume and only suitable for thick walled section. The heat from welding may change the behavior and distort the face of the steel hollow section during installation. Recently, the connection of steel hollow section using bolts or rivet are increasingly popular. This because the bolt hole can be fabricated in the factory and the time consume for the connection work on site can be reduce. Right now, the connection using bolt not only can be done 
using normal bolts and nuts, there are many new design of bolt to be used for hollow section without any excessive works such as flowdrill and blind bolt. The Flowdrill system use a fully threaded bolt fastens the components together without the use of any nuts. Figure 5 shows the schematic process of flowdrill for the steel section.

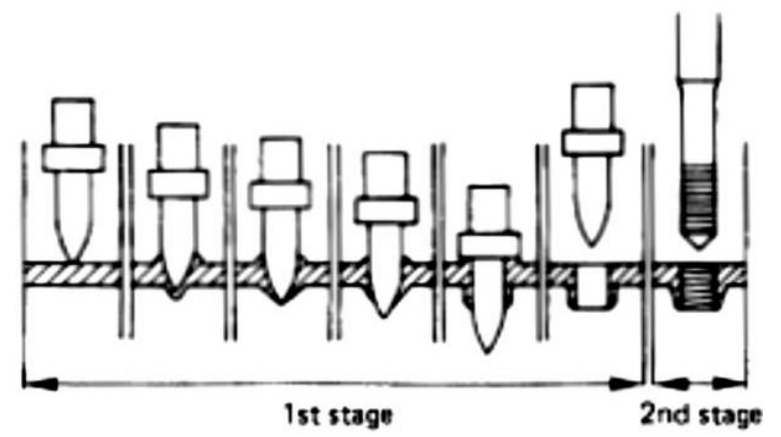

Figure5. Schematic diagram of flowdrill process

(Lee, 2011)

The blind bolt is systems where the bolt can be fasten on one side only. The most known blind bolt can be found are Huck blind bolt, Lindapter Hollo bolt and AJAX Oneside bolt. Huck blind bolt is almost similar to rivet. When the Huck blind bolt is fasten to the steel, the jacket or sleeve on the back will folded and act as fastener on the other side of the steel section as shown in Figure 6(a).

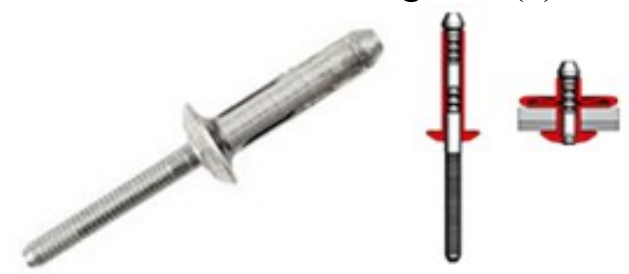

(a) Huck blind bolt

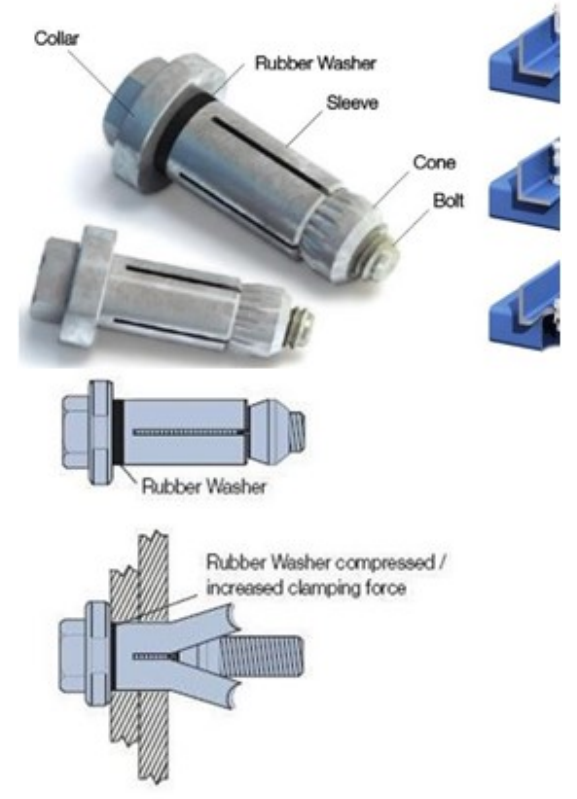

(b) Lindapter Hollo-bolt

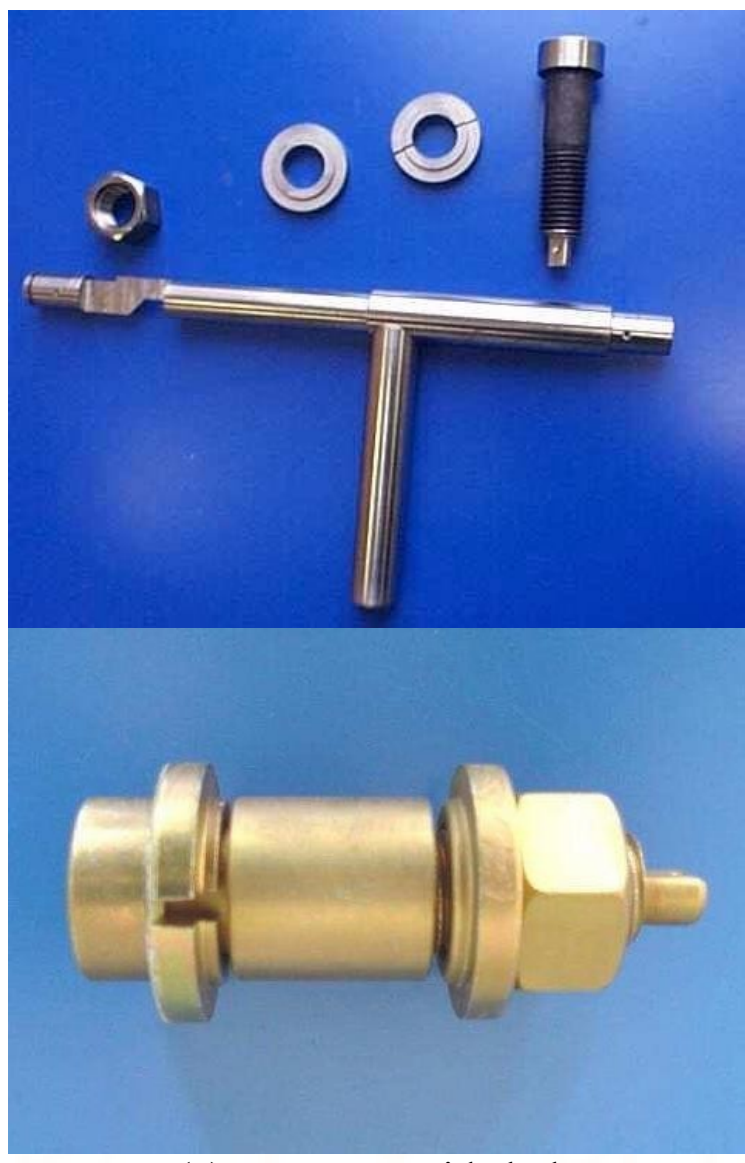

(c) AJAX Oneside bolt

Figure6. Types of blind bolts (Lee, 2011)

The Lindapter hollo-bolt also has a sleeve on the bolt. However, the function of the sleeve is different than Huck blind bolt sleeve. The sleeve of hollo bolt will expand when the bolt is fastened and will hold the component together. Unlike Huck blind bolt and hollo-bolt, AJAX bolt have foldable washer to be insert trough the bolt hole. Once the washer in the other side of the hole, the washer will turn back to original shape and the bolt can be fasten on outer side just like the other bolts.

Even though connection using bolt is not provide strength and stiffness as welding connection, many research have been done to improve the strength and stiffness of bolt connection system. Gardner and Goldsworthy (2005) reported that by just using the blind bolts without any extension to the bolts, the strength of the steel tube wall is not sufficient to resist the bolt heads that pulled out causing massive outward deformation to the steel tube around the bolt holes. With the provision of extension onto the blind bolts, the load failure has increased by $20 \%$. Other than that, the thicknesses and types of end plates are also affecting the stiffness and strength of the blind bolts connection (Wang et al., 2009). 
In 2012, Wang and Guo conducted a study on the connection of steel beam and concrete filled thinwalled steel tubes. Their study was focusing on the effect of connections of flush and extended end plates onto two (2) different thicknesses of the steel hollow tubes namely $1.5 \mathrm{~mm}$ and $3 \mathrm{~mm}$ using extended blind bolt. They showed that extended end plate shows better result compare to the flush end plate. Other than that, the thicker steel tubes have lower deformation and higher moment capacity compare to the thinner steel tubes. Moreover, there was no sign of bending or shear deformation of the bolts in the tests except for the concrete near the bolts in tension which was cracked.

\section{Design consideration}

There are many design codes and standard specifications that address the design of concrete filled steel tubular members such as Eurocode 4 (EC4) and American National Standard Institute (ANSI) where all of them are applicable for the circular and rectangular concrete filled steel tube member. For the concrete filled steel tube members, there are some limitations for the confine concrete to be followed such as steel contribution ratio or confinement ratio and slenderness ratio, $\mathrm{D} / \mathrm{t}$ for circular or $\mathrm{B} / \mathrm{t}$ for rectangular and square section. Table 1 shows the equation for limitation for the EC4 and ANSI/AISC 360-10.

Table 1: Scope of limitation of CFST for

$$
\text { EC4 and ANSI }
$$

\begin{tabular}{|c|c|c|}
\hline & $\mathrm{EC} 4$ & $\begin{array}{c}\text { ANS I/A ISC } \\
360-10\end{array}$ \\
\hline $\begin{array}{l}\text { Confinement } \\
\text { ratio/steel } \\
\text { rnntrihution } \\
\text { ratio }\end{array}$ & 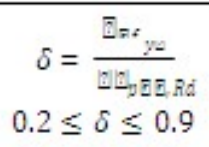 & $\begin{array}{l}\alpha=\frac{\sqrt{7}-}{18} \\
\alpha \geq 1 \%\end{array}$ \\
\hline $\mathrm{D} / \mathrm{t}$ (Circular) & $\frac{\bar{t}}{t} \leq 90\left(\frac{235}{f_{y}}\right)$ & $\frac{\pi}{t} \leq 0.31\left(\frac{\sqrt{7}}{\frac{\pi}{7}}\right)$ \\
\hline $\begin{array}{c}\mathrm{B} / \mathrm{t} \\
\text { (Rectangular) }\end{array}$ & $\left.\frac{\overline{2}}{t}=\right\lrcorner \angle v \frac{235}{f_{y}}$ & $\frac{\sqrt{2}}{t}=\nu v \frac{\sqrt{n}}{f_{y}}$ \\
\hline
\end{tabular}

For design member under axial compression and flexural member, Han et al. (2014) simplified the equation and express the equation in term of SI and FSI respectively. The expressions are given as follow:

$$
\begin{aligned}
& S \text { ? 目 }=\frac{\square_{u}}{-}
\end{aligned}
$$

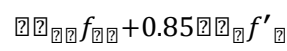

$$
\begin{aligned}
& \text { 2 } S S I=\frac{\vartheta_{u}}{-} \\
& f_{\text {回回回p }}
\end{aligned}
$$

Where $\mathrm{Nu}$ and $\mathrm{Mu}$ is the cross-sectional strength and the flexural strength of the CFST cross section of the CFST columns predicted by codes or specifications respectively, As and Ac are the crosssectional area of steel and concrete, respectively; fy and f'c are the yield strength for steel and the cylinder strength for concrete, respectively and $\mathrm{Zp}$ is the plastic section modulus of hollow steel tube.

The Steel Construction Institute (SCI) and The British Constructional Steelwork Association (BCSA) have provided design guideline manuals for connection of steel hollow section according to the EC3 namely P358 and P398. These guidelines have been made thoroughly according to the previous researches and EC3 specification code, and it cover for all types of connections even with different types of bolt. However these guidelines are for structural hollow section only.

\section{Concrete filled steel tubes applications and developments}

Concrete filled steel tubes have been widely used around the world as compressive member for many years to avoid having large size of columns. In highrise structures, the CFST connected to steel beam or $\mathrm{RC}$ beam to form composite frame structures and often combined with other lateral load resisting systems such as shear wall.

Recently, Han et al. (2014) has conduct a research that focus to the development and advance application of concrete filled steel tube members particularly in China. Most of the major construction in China has been constructed by integrated the CFST into their design. This allowed them to finish the constructions much faster. Figure7(a) shows the Canton Tower in Guangzhou, China using circular section of CFST as their structural members. The tower is 454 meters high and consists of twenty four inclined CFST around the tower with the diameter of $2000 \mathrm{~mm}$ and $50 \mathrm{~mm}$ thickness.

Figure 7(b) shows the Wangcang East River Bridge, which was built in 1992, one of the earliest CFST arch bridges in China. Steel tubes with a diameter of $800 \mathrm{~mm}$ and a thickness of $10 \mathrm{~mm}$ are used for upper and lower chords and connected by two plates to form dumbbell shape for the main arch and the total depth is 2 meters. 


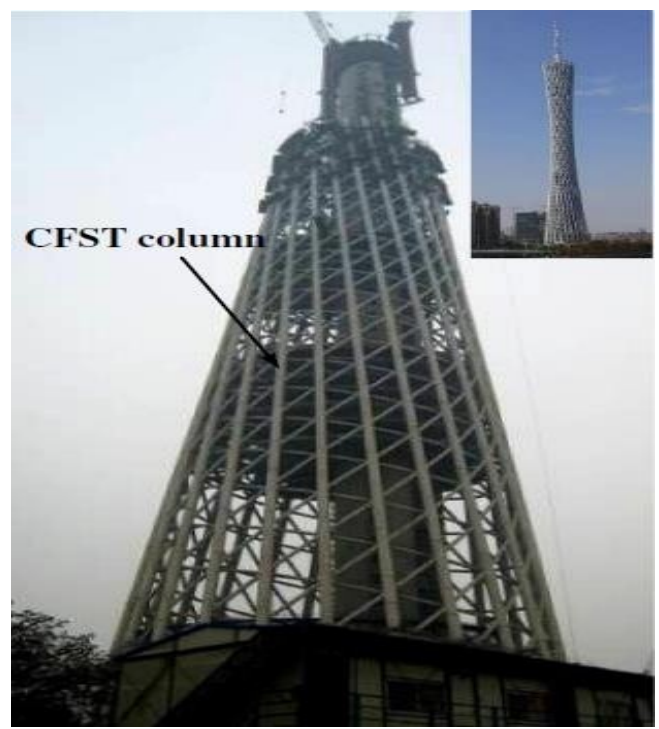

(a) Canton tower

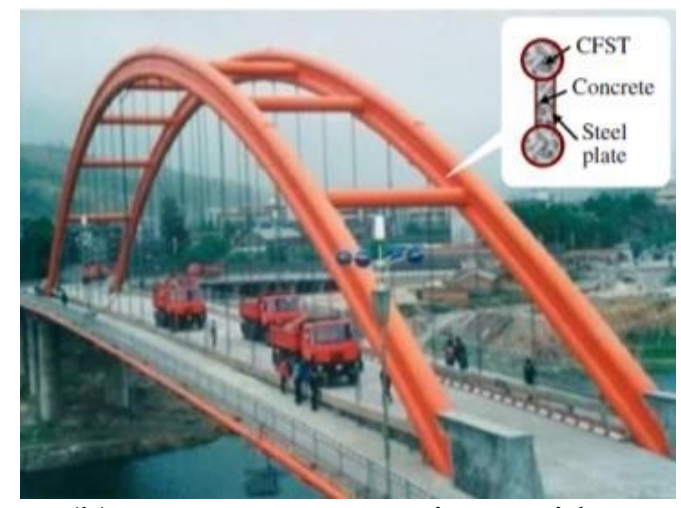

(b) Wangcang East River Bridge

Figure7. Major construction in China using CFST as structural member (Han et al., 2014)

\section{Concluding remarks}

In the past decades, research and application of concrete filled steel tube structures have rapidly develop in all over the world; the scope of "concrete-filled steel tube" has been extended greatly by researchers and engineers. Some typical applications of concrete-filled steel tubular members in buildings and bridges and basic design approaches from different code and standard are presented and compared.

The concrete-filled steel tube structure can be treated as an alternative system to the steel or the reinforced concrete system. The thorough comparison of advantages and disadvantages of the CFST system with the steel and RC system, the connection system, and the space truss structural system as well as the life-cycle performance evaluation should be conducted in the future.

\section{References}

1. Y. M. Alostaz and S. P. Schneider, "Analytical Behavior of Connections to Concrete-Filled Steel Tubes", Journal of Constructional Steel Research, 40(2): pp 95-127, 1996.

2. American National Standard, Specification for Structural Steel Buildings (ANSI/AISC 360-10), Chicago, Illinois, 2010.

3. Australian Standard, Steel structures (AS 4100), Australia, 1998.

4. Y. H. Choi, "A modified AISC P-M Interaction Curve for Square Concrete Filled Tube BeamColumns", Civil and Environmental Engineering, University of Illinois, Urbana, Illinois, 2004.

5. C. Petrus, A. H. Hanizah, I. Azmi and D. N. Joe, "Bond Strength in Concrete Filled Built -Up Steel Tube Columns with Tab Stiffeners", Canadian Journal of Civil Engineering, 2011.

6. C. Petrus, A. H. Hanizah, I. Azmi and G. Parke, "Experimental Behaviour of Concrete Filled Thin Walled Steel Tubes with Tab Stiffeners", Journal of Constructional Steel Research, 66, pp 915-922, 2010.

7. Eurocode 4, Design of composite steel and concrete structures: Part1.1 (BS EN 1994-1-1): General rules and rules for buildings. ENV 1992.

8. A. Z. Y. H. Fam, "Concrete-Filled FiberReinforced Polymer Tubes for Axial and Flexural Structural Members", University of Manitoba, Canada, 2000.

9. A. P. Gardner and H. M Goldsworthy, "Experimental Investigation of the Stiffness of Critical Components in a Moment-Resisting Composite Connection." Journal of Constructional Steel Research, 61(5): pp 70926, 2005.

10. L. H. Han, G. H. Yao and X. L. Zhao, "Tests and calculations for hollow structural steel (HSS) stub columns filled with self-consolidating concrete (SCC)", Journal of Constructional Steel Research, 61, pp 1241-1269, 2005.

11. M. F. Hassanein, O. F. Kharoob and Q. Q. Liang, "Circular Concrete-Filled Double Skin Tubular Short Columns with External Stainless Steel Tubes under Axial Compression", ThinWalled Structures, 73, pp 252-263, 2013. 
International Journal of Trend in Scientific Research and Development (IJTSRD) | ISSN: 2456-647

12. "Joints in Steel Construction: Simple Joints to Eurocode 3 (P358)", The Steel Construction Institute and The British Constructional Steelwork Association, 2011.

13. "Joints in steel construction: Moment-resisting joints to Eurocode 3 (P398)", The Steel Construction Institute and The British Constructional Steelwork Association, 2011.

14. Y. Kurobane, J. A. Packer, J. Wardenier and N. Yeomans, "Design Guide: For Structural Hollow Section Column Connections", CIDECT, Germany.

15. J. Lee, "Blind Bolted Connections for Steel Hollow Section Columns in Low Rise Structures", Department of Civil and Environmental Engineering, The University of Melbourne, Australia, 2011.

16. W. Li, L. H. Han and T. M. Chan, "Tensile Behaviour of Concrete-Filled Double-Skin Steel Tubular Members", Journal of Constructional Steel Research, 99, pp 35-46, 2014.

17. S. P. Schneider and Y. M. Alostaz, "Experimental Behavior of Connections to
Concrete-filled Steel Tubes", Journal of Constructional Steel Research, 45(3): pp 321352, 1998.

18. Z. Tao, L. H. Han and Z. B. Wang, "Experimental Behaviour of Stiffened ConcreteFilled Thin-Walled Hollow Steel Structural (HSS) Stub Columns", Journal of Constructional Steel Research, 61(7), pp 962-983, 2005.

19. J. F. Wang and S. P. Guo, "Structural Performance of Blind Bolted End Plate Joints to Concrete-Filled Thin-Walled Steel Tubular Columns", Thin-Walled Structures, 60: pp 5468, 2012.

20. J. F. Wang, L. H. Han and B. Uy, "Behaviour of Flush End Plate Joints to Concrete-Filled Steel Tubular Columns", Journal of Constructional Steel Research, 65(4): pp 925-939, 2009.

21. Y. F. Yang, L. H. Han, and B. H. Sun, "Experimental Behaviour of Partially Loaded Concrete Filled Double-Skin Steel Tube (CFDST) Sections", Journal of Constructional Steel Research, 71, pp 63-73, 2012. 